\title{
Article
}

\section{Choose Your Future: A feminist perspective on Construction 4.0 as Techno-Utopia or Digital Dystopia}

Barrett, Jennifer Eve

Available at https://clok.uclan.ac.uk/32878/

Barrett, Jennifer Eve orcid iconORCID: 0000-0002-6795-1615 (2020) Choose Your Future: A feminist perspective on Construction 4.0 as Techno-Utopia or Digital Dystopia. Proceedings of the Institution of Civil Engineers:

Management, Procurement and Law, 173 (1). pp. 1-5. ISSN 1751-4304

It is advisable to refer to the publisher's version if you intend to cite from the work. http://dx.doi.org/10.1680/jmapl.20.00003

For more information about UCLan's research in this area go to http://www.uclan.ac.uk/researchgroups/ and search for <name of research Group>.

For information about Research generally at UCLan please go to http://www.uclan.ac.uk/research/

All outputs in CLoK are protected by Intellectual Property Rights law, including Copyright law. Copyright, IPR and Moral Rights for the works on this site are retained by the individual authors and/or other copyright owners. Terms and conditions for use of this material are defined in the policies page.

\section{CLoK}

Central Lancashire online Knowledge www.clok.uclan.ac.uk

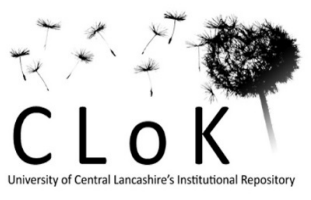




\section{Accepted manuscript \\ doi: 10.1680/jmapl.20.00003}

\section{Accepted manuscript}

As a service to our authors and readers, we are putting peer-reviewed accepted manuscripts (AM) online, in the Ahead of Print section of each journal web page, shortly after acceptance.

\section{Disclaimer}

The AM is yet to be copyedited and formatted in journal house style but can still be read and referenced by quoting its unique reference number, the digital object identifier (DOI). Once the AM has been typeset, an 'uncorrected proof' PDF will replace the 'accepted manuscript' PDF. These formatted articles may still be corrected by the authors. During the Production process, errors may be discovered which could affect the content, and all legal disclaimers that apply to the journal relate to these versions also.

\section{Version of record}

The final edited article will be published in PDF and HTML and will contain all author corrections and is considered the version of record. Authors wishing to reference an article published Ahead of Print should quote its DOI. When an issue becomes available, queuing Ahead of Print articles will move to that issue's Table of Contents. When the article is published in a journal issue, the full reference should be cited in addition to the DOI. 


\section{Accepted manuscript doi: 10.1680/jmapl.20.00003}

Submitted: 31 January 2020

Published online in 'accepted manuscript' format: 04 April 2020

Manuscript title: Choose Your Future: A Feminist Perspective on Construction 4.0 as Techno-Utopia or Digital Dystopia

Author: Jenni Barrett

Affiliation: Faculty of Culture \& Creative Industries, University of Central Lancashire, Preston, PR1 2HE, United Kingdom.

Corresponding author: Jenni Barrett, Faculty of Culture \& Creative Industries, University of Central Lancashire, Preston, PR1 2HE, United Kingdom. Tel.: 01772893240

E-mail: jebarrett@uclan.ac.uk 


\section{Accepted manuscript \\ doi: 10.1680/jmapl.20.00003}

\section{Abstract}

In 2017, the Chancellor of the Exchequer launched the UK Industrial Strategy, inviting us to "choose the future." Via government support for and investment in digital innovation, particularly in the construction industry and public infrastructure, the Strategy aimed to stimulate the UK's industrial productivity and wealth. This paper examines the Industrial Strategy by applying it within the context of the utopian/dystopian literature genre, and through a feminist lens. The paper finds that the Strategy looks set to deliver outcomes similar to themes of dystopian literature genre which imagine that technological progress can only achieved at the expense of social equity, suggesting that the currently gendered idea of Construction 4.0 could exacerbate current gender divisions and inequalities that currently blight the construction industry. Given more balanced strategic support and investment, Construction 4.0 might actually, in a new reality, offer opportunities to resolve issues of gender equity in the industry. The paper concludes with a timely call to researchers and industry professionals to intersect gender inclusivity across all aspects of future research, innovation, and strategy in relation to Construction 4.0, so that the chosen future will support the careers and contributions of all genders that choose to participate in it. 


\section{Accepted manuscript \\ doi: 10.1680/jmapl.20.00003}

\section{An introduction to the utopia/dystopia genre}

Before Thomas More even coined the term, visions of 'utopia' (More, 1516) (meaning an ideal city or society) have frequently been described as an egalitarian society, and unusually for a historical legacy of writing dominated by men, a feminist one. The city-state of Plato's Republic (Plato, c. 375B.C.E.) was governed by male and female philosopher-guardians. Later, the Land of Cockaigne described in the Kildare Poems around 1330 (Lucas, 1995) was described as a land where women and men could be truly equal. In The Book of the City of Ladies, Christine de Pizan (de Pizan, 1405) went further to describe an ideal city built by women for women, as a refuge from the patriarchy.

Then followed a shift in the utopic vision, suggesting the ideal society as one characterised by economic competitiveness and technological innovation. In New Atlantis (Bacon, 1626), Elizabethan statesman, Francis Bacon, argued that England's utopia would be forged, not by the probity of our social structures, but by our ability to invent machines that could guarantee the country's competitiveness on the world stage, with a clearly binary representation of technological innovation as a masculine pursuit, with nature as symbolically feminine (Aughterson, 2003). This introduced a tension between social aspirations of equity and the more masculine technological endeavour.

At this point, the utopian genre diverges into a tense relationship between social and technological disruption, with themes selecting either the egalitarian society or the technocracy as their ultimate vision. It is precisely this uncomfortable tension between the binary ideals of social and industrial transformation that then generated a darker imagining of our society's 


\section{Accepted manuscript \\ doi: 10.1680/jmapl.20.00003}

future - the dystopia. During and following the last major technological transformation of British society - the Industrial Revolution - emergence of the dystopic novel underlined likely losses to equality, happiness, and welfare, should industry embrace technological innovation and competitiveness at the expense of social needs. In Paris in the Twentieth Century (Verne, 1996) Jules Verne's 1863 novel describes a young man who fails to find happiness despite living in a world with incredible buildings and a worldwide communications network. H.G. Wells (Wells, 1895) subsequently describes a world where equality can be embraced due to the absence of technology, in stark contrast to the world the time traveller inhabits in his own time.

And then The Machine Stops - in E.M. Forster's novel, the antithetical tension between technological progress and social equality is further exposed in eerie resonance with the $21^{\text {st }}$ century digitally networked society. Here, people live alone in underground cells, connected to everyone else in the world by screen, the machine worshipped as a source of all knowledge and freedom (Forster, 1909). The dystopic theme of technocracy over social benefit thus gathers momentum in the twentieth century, notably in Ayn Rand's novella, Anthem (Rand, 1938), in Farenheit 451 (Bradbury, 1953), and in the subsequent cinematic genre from Metropolis to The Matrix.

\section{Choose whose future?}

Perhaps the most recent dystopian thriller to influence construction industry culture is the $U K$ Industrial Strategy (H.M.Government, 2017). Like Lord Chancellor Bacon before him in his New Atlantis, Phillip Hammond, then Chancellor of the Exchequer, presented a utopia (for some) which prioritised technological and industrial prowess which ignored historical gender 


\section{Accepted manuscript \\ doi: 10.1680/jmapl.20.00003}

inequalities.

Launching the strategy in the style of the genre, Mr. Hammond invited us to "choose the future." Yet, the future that male-dominated government invited us to choose, was one which invested heavily in similarly male-dominated industries, and in fields that are traditionally identified with traditional masculinity. For example, the $£ 31$ billion investment fund for expenditure on physical infra-structure and technology, with a focus on house building and construction, was not balanced with comparable investment in the health and social sector (Hammond, 2017). Male employees are still vastly over-represented in the former sector, with women dominate the latter. Furthermore, such investment in physical infrastructure, without a balance of investment in the social infrastructure that supports it, has previously been shown to widen gender employment gaps, the converse reducing these inequalities (De Henau, et al., 2016).

Whilst the Industrial Strategy does mention pay inequalities as a social concern, no mention is made of the gender pay gap (either in construction or elsewhere) or strategies to resolve it. This, together with an absence of support for the unpaid care burden which traditionally falls to women, looks set to exacerbate a 'male breadwinner bias' in the construction industry. In this scenario, women are more likely to leave the industry to allow their higher paid (male) partners to bring in a higher salary, making it more difficult for women to 'fit in' to the male dominated work culture, whilst juggling the burden of caring responsibilities (MacLeavy, 2018). This suggests that the UK government's industrial vision is based on one which promotes and maintains current gender inequalities and makes no 


\section{Accepted manuscript \\ doi: 10.1680/jmapl.20.00003}

attempt to deal with the fact that Construction 4.0 itself is a gendered concept, thus inviting us to choose a future which is predominantly male.

\section{A gendered Construction 4.0}

Conspicuously, the Strategy fails to meaningfully identify those areas for investment needed to make sure that anticipated skills shortages can be filled by both women and men, thus maintaining, even exacerbating, the situation where higher rates of men are attracted to and enter a digitally transformed construction industry. More than 2 million people are employed in the digital sector, and the industry is worth $£ 137 \mathrm{bn}$ to the UK annually. Within this digital sector, only $26 \%$ of those working in it are female. This percentage is rapidly reduced when analysing proportions of women in senior digital roles (UK Commission for Employment and Skills, 2015).

These figures evidence historical and cultural divisions associated with gender and technology. Feminist writers and researchers have frequently highlighted the binary approach to the gendering of ideas: culture (m) and nature (f); reason (m) and emotion (f); hard (m) and soft (f) - with masculine concepts privileged over their feminine counterparts (Harding, 1986). This historical and cultural construction of gender brings with it a strong association between men and machines (Wajcman, 2010), framing technological development as the masculine half of a gendered division of labour (Cockburn, 1985). Consequently, the technological professions, such as engineering, automotive design, and product design, have been dominated by men and thus perceived externally to be a more masculine domain (Kaygan, 2016). 


\section{Accepted manuscript doi: 10.1680/jmapl.20.00003}

This gendering of technology fits into a broader division of women's traditional exclusion from the scientific pursuits, not least the 'noble' professions of architecture and engineering (Fowler \& Wilson, 2004). Historically constructed as rational, objective, and neutral - all characteristics in opposition to both traditional femininity or alternative masculinities (Barnard, et al., 2010), science, engineering, and technology are thus culturally assumed not to be careers for women (Herman, 2015). Women within the engineering environment are then left feeling, and are perceived as, 'inauthentic' (Faulkner, 2007).

Maintaining technological skill levels in line with industry progress also presents a challenge to women as crucial skills development in emerging technologies tends to be achieved via 'aspirational labour.' This requires training and skill level elevation to be completed outside core working hours, which is a challenge to many (but not all) women who tend to adopt the larger share of care responsibilities (Duffy, 2016). Over time, the imbalance in the Gender-Technology Relation (Gill \& Grint, 1995) results in women's continued reduced participation in technological fields, thus entrenching the perception of technology careers as a male domain. Industry 'transformation' associated with that technology is additionally gendered as the qualities inherent in such entrepreneurship - wealth, growth, innovation, risk necessary to deliver it are so closely associated with masculinity, challenging women's abilities to be perceived as, or feel like, credible technology innovators (Humbert \& Brindley, 2015; Marlow \& McAdam, 2015).

These gendered contexts of construction, digital careers, and industry transformation, thus conflate to gender Construction 4.0 as a robustly masculine venture, with a marginalised 


\section{Accepted manuscript \\ doi: 10.1680/jmapl.20.00003}

female workforce (Wajcman, 2004; Walby, et al., 2009). The new data-driven labour associated with emerging practices in architectural, engineering, and other construction professions looks set to disadvantage women (Gardner, 2019).

Investment in the construction industry is, of course, extremely welcome and much needed, but in the absence of targeted investment in initiatives that will close gender gaps and improve equity of opportunity, the Strategy both fails to acknowledge, and also to resolve, the gendered nature of the technologies, skills, and cultures in which it wishes to invest. The Strategy assumes, therefore, that the apprenticeships, education, and careers that it will broker for its implementation and success, will be for men, thus maintaining current gender divisions into the future of construction work.

\section{Diverting the digital dystopia}

But is this digital dystopia an inevitability?

Before we resign ourselves to, or head blindly towards, a digital dystopic future for construction, it would be prudent for scholars and professionals alike to challenge the utopic-dystopic binary tradition, and explore a more fluid representation of the lived experiences and careers of those already in in the construction industry, as well as imagining the careers of those we would like to join it. Departing from the genre's traditional polemic of technological progress versus social equity, can construction's digital future be pro-actively reconstructed as an opportunity for change, rather than a barrier?

Previous research certainly highlights the possibility for the digital environment to become a more equal one, where online identities can assume (and be perceived as) any gender 


\section{Accepted manuscript \\ doi: 10.1680/jmapl.20.00003}

or none. The new digital environments remove the physical visibility of, and therefore distinctions between, gendered bodies (Pickerill, 2015). It has further been argued that this reduces the likelihood of the female body's objectification as the individual is detached from its physical presentation (Shire, 2009; Woodfield, 2000). In addition, the historical requirement (or perceived requirement) for physical strength to work in construction is increasingly countered by the digitalisation of the industry (Agarwal, et al., 2016), where automation and robotics increasingly perform these physical tasks, typically only able to be delivered by men. In turn, this may dilute the existing, related, social conceptualisation of the construction worker (in site operative and professional disciplines) as a body with masculine strength (de Soto, 2019).

The digital network has also provided a much needed forum for women to connect and to network, an activity which, in the construction industry, has been identified as excluding women, imposing a barrier to their career progression. (Barnard, et al., 2010; Amaratunga, et al., 2006; Sang \& Powell, 2012). Digital environments not only enable women to more flexibly network with colleagues and clients in terms of time and location, but also to generate their own voice, driving change via productive conversation, such as in the case of the Women In BIM network (www.womeninbim.org), or further, to respond to workplace and social issues on a global scale by collective action and resistance (Baer, 2016). The construction industry's digital spaces have already widened participation in professional learning (Baruah, 2008), with women in built environment professions now more likely to engage in digital learning and networking environments than their male counterparts (Martensen, et al., 2016). 


\section{Accepted manuscript \\ doi: 10.1680/jmapl.20.00003}

Traditional career structures are forecast to be less attractive, and not necessarily continue to be the norm, for those who engage in the emerging Construction 4.0 workplace (Caven, 2004) . Instead, Construction 4.0 can offer a new, location-independent, flexible environment in which those women (and men) who support families, might thrive. The long-held situation in which women feel obliged to demonstrate compliance with construction's cultures of long hours and presenteeism (Watts, 2009) may begin to change.

\section{Delivering gender equity in Construction 4.0}

Should the sequel to the UK Industrial Strategy rebalance investment in a way that can redefine social and cultural infrastructure in the construction sector, then a new feminist geography of the built environment workplace can evolve (Richardson, 2018). This would require substantial investment for education and skills development that can meaningfully and specifically support women and girls considering, or beginning, digital construction careers. The strategy would need to support businesses and organisations in removing the barriers that hinder women's career progression in the industry, most notably by closing gender pay gaps and neutralising cultures of traditional masculinity.

To fully embrace the gender equity opportunities that the internet-enabled industry can tentatively promise, the digital transformation would need to be paralleled by a cultural one. This cultural shift would need to allow women (and men) to manage their diverse and changing out of office commitments, defining alternative career and reward structures so that the best of construction's talent pool can engage in and deliver their best work. To do this, gender equity must be recognised as an inextricable and crucial element of any digital strategies that are 


\section{Accepted manuscript \\ doi: 10.1680/jmapl.20.00003}

produced, whether at departmental, organisational, institutional, industrial or societal levels. But policy and strategies are insufficient if they are not audited or monitored, or if compliance remains voluntary (Caven \& Navarro-Astor, 2013; Ackrill, et al., 2017). It will be crucial for knowledge transfer to take place between industry and academia as it continues to examine the culture changes associated with Construction 4.0, making sure that policy and strategy continues to be flexible and adaptable to lessons learned (Galea, et al., 2014; Galea, et al., 2015) and that the research agenda remains relevant and significant. It is vital that this future research values the diversity and intersectionality associated with the nature of "women in construction' and applies research methodologies that disaggregate industry data relating to the digital transformation (e.g. BIM adoption, digital skills distribution) according to gender. Future construction research will need to qualitatively investigate the diversity and intersectionality involved in women's experiences of Construction 4.0, so that new policy does not homogenise women's experiences, which only serves to highlight women as 'different', and situate them as part of the problem (Barnard, et al., 2010; Sang \& Powell, 2012).

The author begins this crucial conversation in this paper, and calls upon researchers to support its continuation, and to be diligent in their production of a gender-inclusive digitalised industry.

\section{Conclusion}

A critical examination of the UK Industrial Strategy from a feminist and gender equity perspective has formed the narrative and viewpoints presented in this paper. This critical approach is situated within the wider sociological perspectives of scholars such as Zygmut 


\section{Accepted manuscript \\ doi: 10.1680/jmapl.20.00003}

Bauman and B.F.Skinner, who emphasise the significance of social needs and necessity of social action alongside institutionally driven, utopian technocracy (Varcoe, 1996; Rutherford, 2017). However, its true intention is to highlight amongst researchers and industry professionals alike, that the sizeable and welcome government investment in Construction 4.0 and its built results, in its current form, is not likely to improve equitable participation in the gender-troubled construction industry. The digital environment has the potential to resolve some of the historic barriers and limitations that currently blight our industry and result in some of the worst gender pay gaps and levels of female under-representation in UK business.

This paper, therefore, sounds a timely alarm, calling upon us to echo the Chancellor to choose our future. Incidentally, this phrase has previously been used with great effect but opposite intention, when Renton instructed us to guard against blind consumption of new technology without attention to personal and social needs, in the 1996 film Trainspotting. (Hodge, et al., 1997). Whilst as an industry we must respond to the Chancellor's call and associated strategy, we would do well to temper this with consideration of Renton's plea.

If the industry's social infrastructure does not receive research, innovation, and investment now, in parallel with the broader industrial and technological aspirations, then we accept Construction 4.0 as an industrial development that will take place at the expense of gender equity. May we now subvert the genre and intersect gender inclusivity across all aspects of future research, innovation and strategy in relation to Construction 4.0, so that this utopia might actually be realised, and not dispatched to the long list of the construction industry's dystopian disappointments. 


\section{Accepted manuscript \\ doi: 10.1680/jmapl.20.00003}

\section{References}

Ackrill, R., Caven, V. \& Alaktif, J., 2017. 'Black boxes' and 'Fracture Points': The regulation of gender equality in the UK and French construction industries. International Journal of Human Resource Management, 28(21), pp. 3027-3046.

Agarwal, R., Chandrasekaran, S. \& Sridhar, M., 2016. Imagining Construction's Digital Future. [Online] Available at: https://www.mckinsey.com/industries/capital-projects-andinfrastructure/our-insights/imagining-constructions-digital-future

Amaratunga, D. et al., 2006. Construction Industry and Women: A review of the barriers. Delft, SCRI.

Aughterson, K., 2003. Strange Things So Probably Told: Gender, sexual difference and knowledge in Bacon's New Atlantis. In: Francis Bacon's The New Atlantis: New interdisciplinary essays. Manchester: Manchester University Press, pp. 156-179.

Ayre, M., Mills, J. \& Gill, J., 2013. "Yes, I do belong": The women who stay in engineering. Engineering Studies, 5(3), pp. 1-17.

Bacon, F., 1626. New Atlantis. UK: nk.

Baer, H., 2016. Redoing Feminism: Digital activism, body politics and neoliberalism. Feminist Media Studies, 16(1), pp. 17-34.

Barnard, S., Powell, A., Bagilhole, B. \& Dainty, A., 2010. Researching UK Women Professionals in SET: A critical review of current approaches. International Journal of Gender, Science and Technology, 2(3), pp. 361-381.

Baruah, B., 2008. Gender and Globalisation: Opportunities and constraints faced by women in 


\section{Accepted manuscript \\ doi: 10.1680/jmapl.20.00003}

the construction industry in India. Labor Studies Journal, 35(2), pp. 198-221.

Bradbury, R., 1953. Fahrenheit 451. USA: Ballentine Books.

Caven, V., 2004. Constructing A Career: Women Architects At Work. Career Development International, 9(4/5), pp. 519-531.

Caven, V. \& Navarro-Astor, E., 2013. The Potential for Gender Equality in Architecture: An anglo-spanish comparison. Construction, Management and Economics, 31(8), pp. 874-882.

Cockburn, C., 1985. Machinery of Dominance: Women, men and technical know-how. London: Pluto Press.

De Henau, J., Himmelweit, S., Lapniewska, Z. \& Perrons, D., 2016. Investing In The Care Economy: A gender analysis of employment stimulus in seven OECD countries. Report by the UK Women's Budget Group for the International Trade Union Federation., Brussels: Women's Budget Group.

de Pizan, C., 1405. The Book of the City of Ladies. London: Penguin.

de Soto, B. A.-J. I. J. S. H. H., 2019. Implications of Construction 4.0 to the Workforce and Organizational Structures. International Journal of Construction Management.

Duffy, E., 2016. The Romance Of Work: Gender and aspirational labour in the digital culture industries. International Journal of Cultural Studies, 19(4), pp. 441-457.

Faulkner, W., 2007. 'Nuts and Bolts and People': Gender-troubled engineering identities. Social Studies of Science, 37(3), pp. 331-356.

Forster, E., 1909. The Machine Stops. UK: Archibald Constable. 


\section{Accepted manuscript doi: 10.1680/jmapl.20.00003}

Fowler, B. \& Wilson, F., 2004. Women Architects And Their Discontents. Sociology, 38(1), pp. 101-119.

Galea, N., Loosemore, M. \& Campbell, L., 2014. Gender Equity In Construction Professions: A new institutionalist perspective. Portsmouth, ARCOM, pp. 1111-1119.

Galea, N., Powell, A., Loosemore, M. \& Chappell, L., 2015. Designing Robust And Revisable Policies For Gender Equality: Lessons from the Australian construction industry.. Construction, Management and Economics, 33(5-6), pp. 375-389.

Gardner, N., 2019. New Divisions Of Digital Labour In Architecture. Feminist Review, 123(1), pp. 106-125.

Gill, R. \& Grint, K., 1995. The Gender-Technology Relation: Contemporary theory and research. In: The Gender-Technology Relation: Contemporary theory and research. London: Taylor \& Francis, pp. 1-29.

H.M.Government, 2017. Industrial Strategy: Building a Britain fit for the future, London: H.M.Government.

Hammond, P., 2017. Autumn Budget Speech. s.1.:H.M.Treasury.

Harding, S., 1986. The Science Question In Feminism. New York: Cornell University Press.

Herman, C., 2015. Rebooting and Rerouting: Women's articulations of frayed careers in science, engineering and technology. Gender, Work and Organisation, Volume 22, pp. 324-338.

Hodge, J., Boyle, D. \& Welsh, I., 1997. Trainspotting. Great Britain: Miramax Films.

Humbert, A. \& Brindley, C., 2015. Challenging The Concept Of Risk In Relation To Women's 


\section{Accepted manuscript \\ doi: 10.1680/jmapl.20.00003}

Entrepreneurship. Gender in Management, 30(1), pp. 2-25.

Kaygan, P., 2016. Gender, Technology, and the Designer's Work: A feminist review. Design and Culture, 8(2), pp. 235-252.

Lucas, A., 1995. Anglo-Irish Poems of the Middle Ages. Dublin: Columba.

MacLeavy, J., 2018. Women, Equality, And The UK's EU Referendum: Locating the gender politics of Brexit in relation to the neoliberalising state. Space and Polity, 22(2), pp. 205-223.

Marlow, S. \& McAdam, M., 2015. Incubation Or Induction? Gendered Identity Work In The Context Of Technology Business Incubation. Entrepreneurship Theory And Practice, 39(4), pp. 791-816.

Martensen, M., Ryschka, S., Blesik, T. \& Bick, M., 2016. Collaboration In The Consulting Industry. Business Process Management Journal, 22(4), pp. 693-711.

More, T., 1516. de optimo rei publicae statu deque nova insula Utopia. Habsburg, Netherlands: More.

Pickerill, J., 2015. Bodies, Building and Bricks: Women architects and builders in eight eco-communities in Argentina, Spain, Thailand and USA. Gender, Place and Culture, 22(7), pp. 901-919.

Plato, c. 375B.C.E.. Republic. Athens: nk.

Rand, A., 1938. Anthem. s.1.:Cassell.

Richardson, L., 2018. Feminist Geographies Of Digital Work. Progress In Human Geography, 42(2), pp. 244-263. 


\section{Accepted manuscript \\ doi: 10.1680/jmapl.20.00003}

Rutherford, A., 2017. B.F. Skinner and Technology's Nation: Technocracy, social engineering, and the good life in 20th century America. History of Psychology, 20(3), pp. 290-312.

Sang, K. \& Powell, A., 2012. Gender Inequality In The Construction Industry: Lessons from Pierre Bourdieu. Edinburgh, ARCOM, pp. 237-247.

Shire, K., 2009. Gender And The Conceptualisation Of The Knowledge Economy. In: Gendering The Knowledge Economy. London: Palgrave, pp. 51-79.

UK Commission for Employment and Skills, 2015. Sector Insights: Skills and performance challenges in the digital and creative sector, London: UKCES.

Varcoe, I., 1996. Technocracy and Democratic Politics. In: R. Kilminster \& I. Varcoe, eds. Culture, Modernity and Revolution: Essays in honour of Zygmut Bauman. London: Routledge, pp. 66-101.

Verne, J., 1996. Paris in the Twentieth Century. New York: Random House.

Wajcman, J., 2004. Technofeminism. Cambridge: Polity Press.

Wajcman, J., 2010. Feminist Theories of Technology. Cambridge Journal of Economics, 34(1), pp. 143-152.

Walby, S., Gottfried, H., Gottshall, K. \& Osawa, M., 2009. Gendering The Knowledge Economy. London: Palgrave.

Watts, J., 2009. Leaders Of Men: Women "managing" in construction. Work, Employment \& Society, 23(3), pp. 512-530.

Wells, H., 1895. The Time Machine. UK: William Heinemann.

Woodfield, R., 2000. Women, Work And Computing. Cambridge: Cambridge University Press. 